\title{
Implementasi Pakta Integritas Auditor Inspektorat Dalam Meningkatkan Kinerja Pengawasan Pemerintahan Kabupaten Takalar
}

\author{
Muhammad Arif \\ Program Pascasarjana Magister Administrasi Publik \\ Universitas Muhammadiyah Makassar, \\ Makassar,Indonesia \\ Email: arif.unismuh@live.com
}

\begin{abstract}
The objective of this research is to know audit auditor's performance in Governmental tasks, functions, authority, roles and responsibilities in Takalar District and to know the supporting and inhibiting factors of implementing integrity auditor integrity pact in improving supervision performance of Takalar Regency Government. The method used in this research is descriptive qualitative by using flow, interview, and documentation. Then data analysis techniques through data reduction, data presentation, and deduction of conclusions. The results of research that states that the implementation of the functions, tasks, roles, and responsibilities of operational controls become more controlled morally and ethically, is found with the commitment of the leadership to follow up the personnel problem in order to improve the performance of employees, this commitment is also built at the level of aparaturur both the level of leadership and subordinates to support the integrity exercise pact at the Takalar District inspectorate. While the inhibiting factors are less assertive punishment or loss when dilaktusitas are included other than other inhibiting factors ie there are some items in the statement of integrity pact that is difficult to mention as appropriate and appropriate to the law.
\end{abstract}

Keywords: Implementation; Integrity Pac; Inspectorate

\begin{abstract}
Abstrak
Penelitian ini bertujuan untuk mengetahui implementasi pakta integritas auditor inspektorat dalam tugas, fungsi, wewenang, peran dan tanggung jawab pengawasan Pemerintahan di Kabupaten Takalar dan mengetahui faktor pendukung dan penghambat implementasi pakta integritas auditor inspektorat dalam meningkatkan kinerja pengawasan Pemerintahan Kabupaten Takalar. Metode yang digunakan dalam penelitian ini adalah deskriptif kualitatif dengan menggunakan istrumen observasi, wawancara, dan dokumentasi. Kemudian teknik analisa data melalui reduksi data, penyajian data, dan penarikan kesimpulan. Hasil penelitian menunjukkan bahwa Implementasi pakta integritas dari aspek fungsi, tugas, peran, dan tanggungjawab menunjukkan pengawasan penyelenggaraan pemerintahan menjadi lebih terkontrol secara moril dan etika, ditemukan adanya komitmen pimpinan untuk menindaklanjuti masalah kepegawaian dalam rangka meningkatkan kinerja pegawai, komitmen ini juga terbangun ditingkatan aparaturur baik tingkat pimpinan maupun bawahan untuk mendukung pakta implementasi integritas pada instansi inspektorat Kabupaten Takalar. Sementara faktor penghambat yakni kurang tegasnya sanksi atau hukuman bila pakta integritas dilanggar selain itu faktor penghambat lainnya yaitu terdapat beberapa item dalam pernyataan pakta integritas yang sulit diidentifikasi pelanggaran seperti bersikap jujur dan kepatuhan terhadap undang-undang.
\end{abstract}

Kata Kunci: Implementasi; Pakta Integritas; Inspektorat

Link DOI : http://dx.doi.org/10.31314/pjia.7.1.1-10.2018

Copyright $\odot$ 2018, Publik : (Jurnal Ilmu Administrasi), ISSN: 2301-573X (Print), ISSN: 2581-2084 (Online) 


\section{PENDAHULUAN}

Tantangan profesionalisme aparatur Negara saat ini antara lain, adanya peluang penyalah gunaan wewenang/kekuasaan oleh birokrat yang akan merugikan negara dan masyarakat, mafia hukum, menghadapi persaingan global yang semakin kompleks, dan berbagai masalah krusial lain. Pada saat ini untuk mewujudkan aparatur negara yang bisa dipertanggung jawabkan, reformasi aparatur perlu dilaksanakan secara terusmenerus dengan ditopang oleh motivasi untuk mencari cara yang lebih efektif dan efisien (Effendi,2008). Meskipun sudah menjadi gejala yang sangat umum, ternyata pada setiap konteks sistem budaya masyarakat, secara empirik birokrasi dan birokratisasi terlihat dalam pola perilaku yang beragam. Gejala demikian menunjukkan bahwa birokrasi dan birokratisasi tidak pernah tampil dalam bentuk idealnya (Usman, 2011).

Salah satu indikasi rendahnya kualitas PNS Daerah tersebut adalah adanya pelanggaran disiplin yang banyak dilakukan oleh PNS Daerah. Kementerian Pemberdayaan Aparatur Negara dan Reformasi Birokrasi memperkirakan 40\% dari 4,7 juta pegawai negeri sipil (PNS) di Indonesia memiliki kinerja buruk dan akan diminta menjalani pensiun dini Pengembangan kompetensi sebagaimana yang tertera pada pasal 21 Undang-Undang Nomor 5 Tahun 2014 tentang Aparatur Sipil Negara bahwa pengembangan kompetensi merupakan hak bagi PNS, dengan demikian pemerintah daerah wajib untuk menyediakan sarana dan prasarana untuk pengembangan kompetensi tersebut (Rau, 2016).

Selain pengembangan kompetensi juga dibutuhkan sebuah komitmen melalui kebijakan yang tertuang dalam pakta integritas. Pakta integritas yang ada di Inspektorat Kabupaten Takalar mengharuskan pada setiap pagawai untuk bertanggung jawab secara moril pada apa yang telah mereka setujui. Impelementasi kebijakan inilah yang peneliti telusuri secara aktual dilapangan melalui serangkaian penelitian dengan menggunakan teori implementasi Winter (1990), dengan mengacu pada aspek perilaku hubungan antar organisasi, Perilaku implementor (aparat/birokrat) tingkat bawah, dan perilaku kelompok sasaran yang diarahkan pada peningkatan kinerja pengawasan pemerintah. Selain itu penelitian juga membahas faktor-faktor yang mempengaruhi implementasi pakta integiritas tersebut dalam meningkatkan kinerja pengawasan pemerintah daerah Kabupaten Takalar.

Untuk ukuran kinerja dinilai dari semakin baik proses audit dan tindak lanjutnya maka kinerja inspektorat dapat dinilai mengalami peningkatan. Pasolong (2010), melihat kinerja merupakan hasil kerja secara kualitas dan kuantitas yang dicapai oleh seseorang dalam melaksanakan fungsinya sesuai dengan tanggungjawab yang diberikan kepadanya. Kinerja inspektorat yang baik akan memberi kontribusi penting pada terwujudnya pemerintahan daerah yang bersih (clean governance) dan sejalan dengan itu juga akan membuka jalan bagi terwujud pemerintahan yang baik (good governance). Meskipun diakui memang, bahwa telah terjadi banyak perubahan yang cukup banyak termasuk lompatanlompatan pembentukan dan kerja kelembagaan negara yang kian melengkapi percaturan politik kenegaraan Indonesia (Prianto, 2011). 
Sejumlah hasil penelitian terkait dengan implementasi pakta integritas telah dilakukan diantaranya penelitian Ansari (2016), menunjukkan bahwa penerapan pakta integritas pada pengadaan barang/jasa pemerintah merupakan salah satu upaya pemerintah dalam rangka mewujudkan pemerintahan yang baik dan bersih (good governance and clean government).

Hasil penelitian Basuki (2010), menunjukkan penguatan integritas pejabat publik yang diinstruksikan oleh Presiden melalui pakta integritas Peraturan Kebijaksanaan dalam Bidang Perencanaan terhadap pejabat belum dapat maksimal, karena monitoring dan evaluasinya ditugaskan kepada Kementrian (negara)

Pendayagunaan Aparatur Negara yang secara administratif ketatanegaraan tidak mempunyai kompetensi yang sempurna. Hasil penelitian Zaini (2014), menunjukkan pakta integritas yang ditandatangani bahkan disumpah tinggallah pakta integritas, ketika berhadapan dengan kepentingan yang dianggap lebih besar oleh para oknum misalnya pertaruhan jabatan disebuah instansi. Dari sejumlah hasil penelitian yang terkait implementasi pakta integritas masih belum ditemukan sejumlah penjelasan yang menjelaskan secara mendalam mengenai implementasi pakta integritas dalam meningkatkan kinerja pengawasan yang dilakukan oleh inspektorat Kabupaten.

Berbeda dari penelitian sebelumnya penelitian ini akan menganalisa implementasi pakta integritas melalui tugas, fungsi, peran dan tanggungjawab inspektorat Kabupaten Takalar, yang akan peneliti telusuri dari kacamata teori implementasi Winter (1990), yang dapat membantu menguraikan implementasi pakta integritas dari aspek prilaku birokrasi guna meningkatkan kinerja pengawasan yang dilakukan oleh inspektorat Kabupaten Takalar,

Di samping itu penelitian ini juga mencermati dari aspek teoritis etika birokrasi (Widodo, 2001; Holilah, 2013), sehingga nilai-nilai seperti efesiensi, Impersonal, merytal system dan nilai responsible menjadi acuan indikator pada penelitian ini sehingga diperoleh faktor pendukung dan penghambat dalam implementasi pakta integritas auditor inspektorat. Berdasarkan sudut pandang dan uraian yang dikemukakan maka penelitian ini bertujuan untuk mengetahui implementasi pakta integritas auditor inspektorat dalam tugas, fungsi, wewenang, peran dan tanggungjawab pengawasan Pemerintahan di Kabupaten Takalar serta mengetahui mengetahui faktor pendukung dan penghambat yang berpegaruh dalam implementasi tersebut.

\section{METODE PENELITIAN}

Penelitian ini menggunakan pendekatan kualitatif, jenis penelitian yang temuan-temuannya tidak diperoleh prosedur statistik atau bentuk hitungan lainnya. Pendekatan kualiitatif dipilih karena dapat digunakan untuk mengungkap dan memahami sesuatu di balik fenomena yang belum diketahui. Adapun jenis penelitian bersifat deskriptif, yaitu untuk mendeskripsikan dan mengkaji data yang diperoleh dari hasil wawancara mendalam (indepth intervew), observasi, dan dokumentasi.

Penelitian ini dilaksanakan di Kantor Inspektorat Kabupaten Takalar sebagai implementor pakta integritas dan SKPD terkait seperti Badan Kepegawaian Daerah Kabupaten Takalar sebagai kelompok sasaran dari kinerja pengawasan Inspektorat. Informan kunci berasal dari Inspektorat Kabupaten Takalar. 
Teknik analisis data dalam penelitian ini menggunakan model Miles dan Huberman yang mengemukakan bahwa aktifitas dalam analisis data kualitatif dilakukan secara interaktif dan berlangsung secara terus menerus dan sampai tuntas, sehingga datanya sudah jenuh. Aktifitas dalam analisis data, yaitu data reduction, data display, dan conclusion drawing/verification (Sugiyono, 2011).

\section{HASIL DAN PEMBAHASAN}

\section{Implementasi Pakta Integritas Auditor Inspektorat dalam meningkatkan Kinerja Pengawasan Pemerintahan Kabupaten Takalar}

Berdasarkan hasil wawancara dapat diketahui bahwa implementasi pakta integritas terkait fungsi auditor inspektorat dalam pengawasan penyelenggaraan pemerintahan menjadi lebih terkontrol secara moril dan etika. Hal ini mengindikasikan bahwa pakta integiritas dapat menjaga fungsi pengawasan yang dilakukan inspektorat tanpa adanya pengawasan melekat dalam artian sebagai langkah pencegahan agar fungsi inspektorat tidak meleceng dari fungsi yang semestinya yaitu melakukan Pengawasan Penyelenggaraan Pemerintahan, Pembangunan, serta Pengelolaan Keuangan dan Kekayaan Daerah di Kabupaten Takalar.

Apalagi saat ini publik selalu menuntut kualitas pelayanan publik dari birokrat, meskipun tuntutan ini tidak sesuai dengan harapan karena pelayanan publik secara empiris yang terjadi selama ini masih ditandai dengan hal-hal seperti berbelit-belit, lambat, mahal, ketidakpastian melelahkan. Dalam keadaan seperti itu terjadi karena orang masih diposisikan sebagai pihak yang "melayani" malah tidak dilayani (Mahsyar, 2011).
Berdasarkan hasil wawancara dapat diketahui bahwa untuk kelancaran dan efektifnya pengawasan yang dilakukan Auditor Inspektorat Kabupaten Takalar keberadaan pakta integritas sangat membantu karena akan berpengaruh pada pekerjaan yang dilakukan mengingat pengawasan yang dilakukan mengedepankan integritas dan profesionalisme.

Berdasarkan hasil wawancara dapat diketahui bahwa pakta integritas telah disosialisasikan kepada ASN yang ada di Inspektorat Kabupaten Takalar. Dalam pelaksanaan tugas ditemukan pelanggaran pakta integritas maka akan diproses sesuai dengan ketentuan yang berlaku. Berdasarkan hasil wawancara dapat diketahui bahwa dalam pelaksanaan tugas bila terdapat indikasi pelanggaran maka dapat dikenakan sanksi berdasarkan peraturan perundang-undangan yang berlaku.

Berdasarkan hasil wawancara dapat dipahami bahwa tidak dapat disimpulkan bahwa terjadi pelanggaran pakta integritas di lingkungan inspektorat Kabupaten Takalar hal ini dikarenakan perjanjian tersebut berdasarkan kesadaran aparatur yang telah menyetujui untuk menandatangani pakta integritas dan secara aktual memang tidak ada temuan pelanggaran pakta integritas di lingkugan inspektorat Kabupaten Takalar.

Berdasarkan hasil wawancara dapat diketahui bahwa terdapat tanggungjawab auditor terkait program pengawasan yaitu pada pemeriksaan tahunan, pemeriksaan pengaduan masyarakat dan bertanggung jawab pada pengembangan rencana kerja dan program audit jangka panjang dan tahunan untuk mengevaluasi pengendalian manajemen di setiap kegiatan dan program pemerintah daerah. 


\section{Available Online at http://journal.umgo.ac.id/index.php/Publik \\ Publik : (Jurnal Ilmu Administrasi) Vol 7 (1), Juni 2018}

Jurnal IImu Administrasi

Berdasarkan hasil wawancara dapat diketahui bahwa tanggungjawab pengawasan yang dilakukan auditor diimpelementasikan secara berjenjang dari level bawahan sampai pada level pimpinan kemudian untuk pengukuran kinerja pengawasan dapat dilihat dari tindaklanjut OPD serta tingkatan yang lebih tinggi seperti APIP, BPK dan LKPD.

Berdasarkan hasil wawancara dapat diketahui bahwa pakta integritas menjadi sebuah kredit point atau pendukung kinerja pengawasan yang dilakukan oleh auditor inspektorat tanpa danya statuta atau sanksi dan impact yang muncul adalah adanya sedikit perubahan pada tingkat kedisiplinan aparatur.

Berdasarkan hasil wawancara dapat diketahui bahwa inspektorat memiliki kewenangan dalam melakukan pemeriksaan terhadap proses pelaksanaan pengadaan barang/jasa yang sesuai dengan tugas dan fungsinya serta kewenangan lainya yaitu melaporkan hasil pemeriksaan kepada pimpinan dan BPKP.

Berdasarkan hasil wawancara dapat diketahui bahwa bila terjadi pelanggaran yang membuat aparatur inspektorat menyalahgunakan wewenang yang diamanatkan maka akan diberikan peringatan mengenai perbaikan kinerja dan situasi ini dapat ditindaklanjuti oleh APIP sebagai pengawasan ditingkatan yang lebih tinggi yaitu inspektorat provinsi.

Berdasarkan hasil wawancara dapat dipahami bahwa kewenangan inspektorat Kabupaten Takalar terbatas pada pengawasan lingkup internal dalam hal ini OPD yang diawasi kinerjanya kemudian laporan pengawasan tersebut disampaikan kepada bupati sebagai pejabat pembina kepegawaian yang dapat menindaklanjuti hasil audit yang dilakukan oleh inspektorat.
Berdasarkan hasil wawancara dapat diketahui bahwa peran auditor lebih kepada temuan-temuan mengenai pencatatan barang yang terdapat dalam Organisasi Perangkat Daerah di Kabupaten Takalar lebih lanjut ditekankan juga adalah ketidak disiplinan pegawai yang menjadi

catatan dalam laporan hasil pemeriksaan.

Berdasarkan hasil wawancara dapat diketahui bahwa dapat dipahami bahwa pakta integritas sangat mendukung peran auditor inspektorat dalam proses terciptanya akuntabilitas dan transparansi pengelolaan keuangan di daerah hal ini dapat menjadi kontrol untuk meminimalisir terjadinya pelanggaran dalam pengelolaan keuangan dan barang milik daerah.

Secara keseluruhan implementasi pakta integritas dari aspek fungsi, tugas, peran, dan tanggungjawab menunjukkan pengawasan penyelenggaraan pemerintahan menjadi lebih terkontrol secara moril dan etika. Hal ini mengindikasikan bahwa pakta integiritas dapat menjaga fungsi pengawasan yang dilakukan inspektorat tanpa adanya pengawasan melekat dalam artian sebagai langkah pencegahan agar fungsi inspektorat tidak meleceng dari fungsi yang semestinya yaitu melakukan pengawasan Penyelenggaraan Pemerintahan, Pembangunan, serta Pengelolaan Keuangan dan Kekayaan Daerah di Kabupaten Takalar.

Pada aspek pelaksanaan tugas pakta integritas sangat membantu karena akan berpengaruh pada pekerjaan yang dilakukan mengingat pengawasan yang dilakukan mengedepankan integritas dan profesionalisme. pakta integritas juga telah disosialisasikan kepada ASN yang ada di Inspektorat Kabupaten Takalar. Dalam pelaksanaan tugas jika ditemukan pelanggaran pakta integritas maka akan 
diproses sesuai dengan ketentuan yang berlaku dari hasil penelitian juga diperoleh penjelasan bahwa belum ditemukan indikasi pelanggaran pakta integritas dalam pelaksanaan tugas aparatur di lingkungan inspektorat Kabupaten Takalar. Hal ini terkonfirmasi dari Badan Kepegawaian Daerah Kabupaten Takalar. Perjanjian pada pakta integritas dilakukan berdasarkan kesadaran aparatur yang telah menyetujui untuk menandatangani pakta integritas dan secara aktual dilapangan tidak ada temuan pelanggaran pakta integritas di lingkugan inspektorat Kabupaten Takalar.

Pada aspek tanggung jawab ditemukan bahwa terdapat tanggung jawab auditor terkait program pengawasan yaitu pada pemeriksaan tahunan, pemeriksaan pengaduan masyarakat dan bertanggung jawab pada pengembangan rencana kerja dan program audit jangka panjang dan tahunan untuk mengevaluasi pengendalian manajemen di setiap kegiatan dan program pemerintah daerah. Kemudian hasil penelitian menunjukkan tanggungjawab pengawasan yang dilakukan auditor diimpelementasikan secara berjenjang dari level bawahan sampai pada level pimpinan kemudian untuk pengukuran kinerja pengawasan dapat dilihat dari tindaklanjut OPD serta tingkatan yang lebih tinggi seperti APIP, BPK dan LKPD. Selanjutnya terdapat indikator kinerja pengawasan yang dilakukan oleh auditor inspektorat mulai dari persentasi kelulusan sertifikasi aparat pengawas, Level Kapabilitas APIP, Opini Laporan Keuangan, persentasi Penyelesaian Tindak lanjut Rekomendasi BPK pada setiap tahun berkenaan, persentasi Kasus/ Pengaduan di lingkungan Pemda yang ditindaklanjuti, Nilai Evaluasi Implementasi SAKIP Kabupaten Takalar, dan Skor penilaian (Nasional) LPPD Kabupaten Takalar. Semua indikator memiliki target dan realisasi yang dapat berupa persentasi dan capaian status tertentu seperti WTP untuk opini laporan keuangan. Pakta integritas menjadi sebuah kredit point atau pendukung kinerja pengawasan yang dilakukan oleh auditor inspektorat tanpa danya statuta atau sanksi dan impact yang muncul adalah adanya sedikit perubahan pada tingkat kedisiplinan aparatur.

Pada aspek wewenang inspektorat memiliki kewenangan dalam melakukan pemeriksaan terhadap proses pelaksanaan pengadaan barang/jasa yang sesuai dengan tugas dan fungsinya serta kewenangan lainya yaitu melaporkan hasil pemeriksaan kepada pimpinan dan BPKP. Kemudian bila terjadi pelanggaran yang membuat aparatur inspektorat menyalahgunakan wewenang yang diamanatkan maka akan diberikan peringatan mengenai perbaikan kinerja dan situasi ini dapat ditindaklanjuti oleh APIP sebagai pengawasan ditingkatan yang lebih tinggi yaitu inspektorat provinsi. Kewenangan inspektorat Kabupaten Takalar terbatas pada pengawasan lingkup internal dalam hal ini OPD yang diawasi kinerjanya kemudian laporan pengawasan tersebut disampaikan kepada bupati sebagai pejabat pembina kepegawaian yang dapat menindaklanjuti hasil audit yang dilakukan oleh inspektorat.

Pada aspek peran diperoleh hasil penelitian yang menujukkan peran auditor lebih kepada temuan-temuan mengenai pencatatan barang yang terdapat dalam Organisasi Perangkat Daerah di Kabupaten Takalar lebih lanjut ditekankan juga adalah ketidakdisiplinan pegawai yang menjadi catatan dalam laporan hasil pemeriksaan dalam ini pakta integritas sangat mendukung peran auditor inspektorat dalam proses terciptanya akuntabilitas dan transparansi pengelolaan keuangan di 
daerah hal ini dapat menjadi kontrol untuk meminimalisir terjadinya pelanggaran dalam pengelolaan keuangan dan barang milik daerah.

Pada tinjauan teoritis implementasi merupakan suatu aktivitas yang bertalian dengan penyelesaian suatu pekerjaan dengan penggunaan sarana (alat) untuk memperoleh hasil. Sehingga bila dirangkaikan dengan kebijakan publik, maka kata implementasi kebijakan publik dapat diartikan sebagai aktivitas penyelesaian atau pelaksanaan suatu kebijakan publik yang telah ditetapkan/disetujui dengan penggunaan sarana (alat) untuk mencapai tujuan kebijakan (Tahjan, 2008). Dari hasil penelitian ditemukan bahwa terdapat kontrol organisasi, etos kerja dan normanorma profesional yang merupakan salah satu dimensi implementasi (Winter, 1990) hal ini terlihat dari implementasi pakta integritas yang membuat pengawasan penyelenggaraan pemerintahan menjadi lebih terkontrol secara moril dan etika.

\section{Faktor pendukung dan Penghambat Implementasi Pakta Integritas}

Berdasarkan hasil wawancara dapat dipahami bahwa pakta integritas dapat mendukung tugas pengawasan yang dilakukan auditor inspektorat. Hal ini tidak terlepas dari komitmen pimpinan dan aparatur untuk menyetujui perjanjian yang tertuang dalam pakta integritas.

Berdasarkan hasil wawancara dapat dipahami bahwa terdapat komitmen pimpinan untuk menindaklanjuti masalah kepegawaian untuk meningkatkan kinerja pegawai, selanjutnya dari hasil disposisi Bupati ke BKPSDM untuk memberikan tindakan berupa terguran atau SK pelanggaran.

Berdasarkan hasil wawancara dapat diketahui bahwa terdapat komitmen yang terbangun oleh para aparatur baik tingkat pimpinan maupun bawahan untuk mendukung pakta implementasi integritas pada instansi inspektorat Kabupaten Takalar.

Selain komitmen aparatur yang menjadi faktor pendukung Implementasi Pakta Integritas Auditor Inspektorat dalam meningkatkan Kinerja Pengawasan Pemerintahan Kabupaten Takalar juga terdapat faktor SDM yang menjadi keunggulan aparatur inspektorat Kabupaten Takalar.

Berdasarkan data yang sajikan dapat diketahui bahwa terdapat 31 orang dengan jenjang pendidikan S1 dan 4 Orang S2, satu orang S3 dan hanya ada 2 orang SLTA dari 39 orang jumlah pegawai yang ada di Inspektorat Kabupaten Takalar, hal ini mengartikan bahwa keadaan SDM yang ada di Inspektorat Kabupaten Takalar memiliki tingkat pendidikan yang menunjang kinerja aparatur inspektorat Kabupaten Takalar.

Berdasarkan hasil wawancara dapat diketahui bahwa SDM yang ada di Inspektorat Kabupaten Takalar telah melalui sejumlah pelatihan dan pendidikan yang menunjang kinerja pengawasan dan meningkatkan integritas aparatur dalam melaksanakan tugas dan fungsinya hal ini menjadi salah satu faktor pendukung dalam implementasi pakta integritas karena telah ditunjang oleh kapasitas SDM yang baik.

Berdasarkan hasil wawancara dengan informan dapat dipahami bahwa hal yang menghambat implementasi pakta integritas adalah tidak adanya sanksi atau hukuman bila pakta integritas dilanggar, sulit menelusuri mengenai pelanggaran itu betul-betul dilakukan atau tidak.

Berdasarkan hasil wawancara dapat diketahui bahwa terdapat beberapa item dalam pernyataan pakta integritas yang sulit diidentifikasi pelanggaran seperti bersikap jujur dan kepatuhan terhadap 
undang-undang hal ini sulit diidentifikasi sebagai sebuah pelanggaran butuh pendekatan khusus untuk mengidentifikasi hal tersebut.

Berdasarkan hasil wawancara dapat diketahui bahwa pakta integritas dikhususkan pada komitmen personal aparatur yang berfungsi sebagai langkah proaktif dalam pemberantasan korupsi di lingkungan inspektorat Kabupaten Takalar.

Dari penjelasan mengenai faktor penghambat Implementasi Pakta Integritas ini dapat diperoleh kesimpulan bahwa kurang tegasnya sanksi atau hukuman bila pakta integritas dilanggar, sulit menelusuri mengenai pelanggaran itu betul-betul dilakukan atau tidak. terdapat beberapa item dalam pernyataan pakta integritas yang sulit diidentifikasi pelanggaran seperti bersikap jujur dan kepatuhan terhadap undang-undang hal ini sulit diidentifikasi sebagai sebuah pelanggaran butuh pendekatan khusus untuk memberikan sanksi.

Secara keseluruhan terkait hasil penelitian mengenai faktor-faktor yang mempengaruhi Implementasi Pakta Integritas Auditor Inspektorat dalam meningkatkan Kinerja Pengawasan Pemerintahan Kabupaten Takalar ditemukan bahwa faktor pendukung terdiri dari komitmen pimpinan dan aparatur serta kapasitas SDM.

Komitmen pimpinan untuk menindaklanjuti masalah kepegawaian dalam rangka meningkatkan kinerja pegawai dapat dicermati dari hasil disposisi Bupati ke BKPSDM untuk memberikan tindakan berupa terguran atau SK pelanggaran. Kemudian terdapat komitmen yang terbangun oleh para aparatur baik tingkat pimpinan maupun bawahan untuk mendukung pakta implementasi integritas pada instansi inspektorat Kabupaten Takalar.
Selain itu juga terdapat faktor kapasitas SDM yang menjadi keunggulan aparatur inspektorat Kabupaten Takalar yang dapat dilihat dari latar belakang pendidikan sejumlah pelatihan yang telah dilalui aparatur inspektorat yang dapat menunjang kinerja pengawasan dan meningkatkan integritas aparatur dalam melaksanakan tugas dan fungsinya hal ini menjadi salah satu faktor pendukung dalam implementasi pakta integritas karena telah ditunjang oleh kapasitas SDM yang baik. Penguatan organisasi, dengan fokus tata manajemen untuk meningkatkan keberhasilan peran dan fungsi organisasi seperti pada penguatan SDM dan kepemimpinan merupakan bentuk dimensi pengembangan kapasitas (Grindle, 1997).

Sementara faktor penghambat yang ditemukan dalam penelitian ini yakni kurang tegasnya sanksi atau hukuman bila pakta integritas dilanggar, sulit menelusuri mengenai pelanggaran itu betul-betul dilakukan atau tidak. Selain itu terdapat beberapa item dalam pernyataan pakta integritas yang sulit diidentifikasi pelanggaran seperti bersikap jujur dan kepatuhan terhadap undang-undang hal ini sulit diidentifikasi sebagai sebuah pelanggaran butuh pendekatan khusus untuk memberikan sanksi.

\section{PENUTUP}

\section{Kesimpulan}

Implementasi pakta integritas dari aspek fungsi, tugas, peran, dan tanggungjawab menunjukkan pengawasan penyelenggaraan pemerintahan menjadi lebih terkontrol secara moril dan etika hal ini terlihat dari aspek pelaksanaan tugas pakta integritas sangat membantu karena berpengaruh pada pekerjaan yang dilakukan mengingat pengawasan yang dilakukan mengedepankan integritas dan profesionalisme dan secara aktual di 
lapangan tidak ditemukan pelanggaran pakta integritas. Faktor pendukung yang ditemukan dalam penelitiam ini terdiri dari komitmen pimpinan dan aparatur serta kapasitas SDM Sementara faktor penghambat yakni kurang tegasnya sanksi atau hukuman bila pakta integritas

dilanggar, sulit menelusuri mengenai pelanggaran itu betul-betul dilakukan atau tidak. Selain itu terdapat beberapa item dalam pernyataan pakta integritas yang sulit diidentifikasi pelanggaran seperti bersikap jujur dan kepatuhan terhadap undang-undang.

Saran

Diperlukan aturan yang secara khusus mengenai sanksi tegas pelanggaran pakat integritas hal ini bertujuan agar impelementasi pakta integritas menjadi lebih kuat dari posisi legitimasinya. Kewenangan inspektorat daerah masih terbatas dibawah pimpinan kepala daerah sehingga kewenangan pengawasan berfokus pada internal organisasi perangkat daerah namun tidak berlaku pada pejabat pembina kepegawaian oleh karena itu diperlukan kebijakan perluasan kewenangan inspektorat oleh pemerintah pusat. Implementasi pakta integritas memerlukan pimbinaan moral dan etika birokrasi sebelum dokumen pakta integritas yang ditandatangani disetujui oleh aparatur hal ini bertujuan agar pakta integritas dapat dipahami betul oleh aparatur dalam setiap pelaksanaan tugas dilingkungan kerjanya.

\section{DAFTAR PUSTAKA.}

Ansari, Muhammad Insa. (2016). Penerapan Pakta Integritas Pada Pengadaan Barang/Jasa Untuk Mewujudkan Tata Kelola Pemerintah Yang Bersih Integrity
Pact Implementation Of

Procurement Of Goods/Services To

Realize That Clean Government. Jurnal Ilmu Hukum, Vol. 18, No. 3. Basuki, Ahmad. (2010). Pakta Integritas Di Tengah Suramnya Pemberantasan Tindak Pidana Korupsi Di Indonesia. Jurnal Perspektif Volume XV No. 1, 37-49.

Effendi, Taufiq. (2008). Menteri Pendayagunaan Aparatur Negara pada Seminar Pembangunan Sumber Daya Manusia Aparatur Negara. Semarang : Universitas Diponegoro.

Gaffar, Afan, (2009). Politik Indonesia: Transisi Menuju Demokrasi. Yogyakarta : Pustaka Pelajar.

Grindle, M. (1997). Getting good government: capacity building the public sector of developing countries. Boston: Harvard Institute for International Development.

Holilah. (2013). Etika Administrasi Publik. Jurnal Review Politik Volume 03, Nomor 02.

Mahsyar, A. (2011). Masalah Pelayanan Publik di Indonesia dalam Perspektif Administrasi Publik. Otoritas: Jurnal Ilmu Pemerintahan. 1(2).

Marzali, Amri. (2012). Antropologi dan Kebijakan Publik. Jakarta : Kencana Prenada Media Group.

Pasolong, Harbani. (2010). Teori Administrasi Publik. Bandung: Alfabeta.

Prianto, A. L. (2011). Good Governance dan Formasi Kebijakan Publik NeoLiberal. Otoritas: Jurnal Ilmu Pemerintahan, 1(1).

Rau, Muh. Jusman. (2016). Hubungan Motivasi Dan Disiplin Kerja Dengan Kinerja Pegawai Di 
Puskesmas Sangurara Kecamatan

Palu Barat Kota Palu.

jurnal.untad.ac.id. diakses 25

Oktober 2016.

Sugiyono. (2011). Memahami Penelitian

Kuantitatif, Kualitatif dan $R \& D$.

Bandung: Alfabeta.

Tahjan, H. (2008). Implementasi Kebijakan

Publik. Bandung : RTH

Usman, J. (2011). Implementasi Kebijakan

Tata Kelola Pemerintahan Daerah

Dengan Semangat Euforia

Demokrasi Lokal. Otoritas: Jurnal

Ilmu Pemerintahan, 1(1). 